\title{
日本鉄鋼業における省エネルギーの現状と今後
}

\section{Present status and future prospects of energy conservation in Japanese steel industry}

\author{
一田守政* ·小野 透***米澤公敏*** \\ Morimasa ICHIDA, Tooru ONO and Kimitoshi YONEZAWA
}

(Received February 13, 2008)

\begin{abstract}
The energy conservation achievements realized by the Japanese steel industry since the first oil crisis (1973) were reported. In addition, the outline of the self action plan on environmental conservation announced by the Japan Iron and Steel Federation in December 1996, the new energy-saving technologies containing next generation iron- and steel-making technologies and the development problems it should tackle toward the realization of a sustainable society were clarified in this paper.
\end{abstract}

Key Words: Global Warming, Steel Industry, Energy Conservation, Recycling, Sustainable Society

\section{1. 緒 言}

近年、経済成長に伴う化石燃料の消費量拡大により、大 気中の二酸化炭素 (以下 $\mathrm{CO}_{2}$ ) 濃度が増大している。代表 的な温室効果ガスである $\mathrm{CO}_{2}$ の濃度増加は深刻な環境問 題の一つである地球温暖化を進行させていると言われて いる。一方 $\mathrm{CO}_{2}$ 濃度と地球温暖化の関連には諸説があり、 $\mathrm{CO}_{2}$ による地球温暖化のメカニズムを疑問視する声も少な 〈ない1)。しかし、省エネルギーが $\mathrm{CO}_{2}$ 削減と資源節約の 有効な対策であることに異論はない。本論文では、第一次 石油危機（1973 年）以降日本鉄鋼業が取り組んできた省工 ネルギーの実績を紹介すると同時に持続可能な (sustainable) 社会に向けて鉄鋼業が取り組むべき開発課題を明確にす る。

\section{2. 鉄鋼生産量とエネルギー消費}

1951 年以降急速に増大してきた鉄鋼生産量は 1973 年に 粗鋼 120 百万 $\mathrm{t} /$ 年、銑鉄 91 百万 $\mathrm{t} /$ 年に到達した (Fig.1)。 1973 年以降の鉄鋼生産量は粗鋼 100 百万 $\mathrm{t} /$ 年、銑鉄 80 百万 $\mathrm{t} ／$ 年レベルで推移し、2000 年以降増加傾向にある。

2.1 石油危機以降のエネルギー消費量推移

1973 年の第一次石油危機以降日本鉄鋼業が取り組んでき た省エネルギーの取り組みと実績イメージを Fig.2に示す。 エネルギー原単位 (Net consumption) は 1973 年度を 100 と

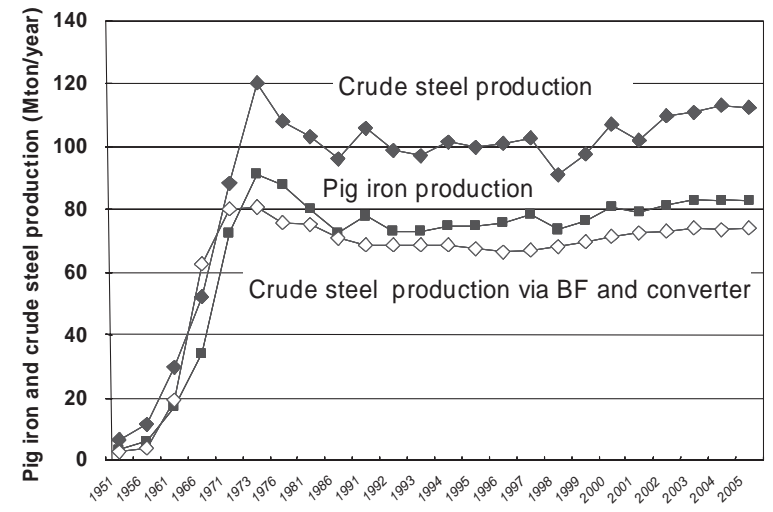

Fig.1 Change in pig iron production and crude steel in Japan.

すると 1980 年度には 89 と 10\% 強低減し、1985 年度には 80 と $20 \%$ 低減した。すなわち 1985 年度には $20 \%$ の省エネ ルギーを達成した ${ }^{2,3)}$ 。具体的な取り組みは、各設備におけ るきめ細かな操業改善、工程連続化や工程省略等の生産設 備の高効率化、排熱回収設備の導入や副生ガス回収強化等 の排エネルギー回収の 3 点である ${ }^{2,3)}$ 。とくに排エネルギー 回収設備の普及率向上の貢献度が大きい。1990年以降には、 上記の鉄鋼業界内での省エネルギーと同時に社会で発生す る廃棄物のリサイクルによる省エネルギーにも積極的に取 り組んでいる。

*新日本製鐵(侏 環境・プロセス研究開発センター（† 293-8511 千葉県富津市新富 20-1）

Nippon Steel Corporation Environment \& Process Technology Center (20-1,Shintomi, Futtsu, Chiba, 293-8511, JAPAN)

**新日本製鐵(株) 技術総括部エネルギー技術 $\mathrm{Gr}$ （ ₹ 100-8071 東京都千代田区大手町 2-6-3

Nippon Steel Corporation, Technical Administration \& Planning Department, Energy Technical Group

(2-6-3, Otemachi , Chiyoda-ku, Tokyo, 100-8071, JAPAN )

****新日本製鐵株 技術総括部技術総括 $\mathrm{Gr}$ （ ₹ 100-8071 東京都千代田区大手町 2-6-3）

Nippon Steel Corporation, Technical Administration \& Planning Department, Technical Administration \& Planning Group (2-6-3, Otemachi , Chiyoda-ku, Tokyo, 100-8071, JAPAN ) 


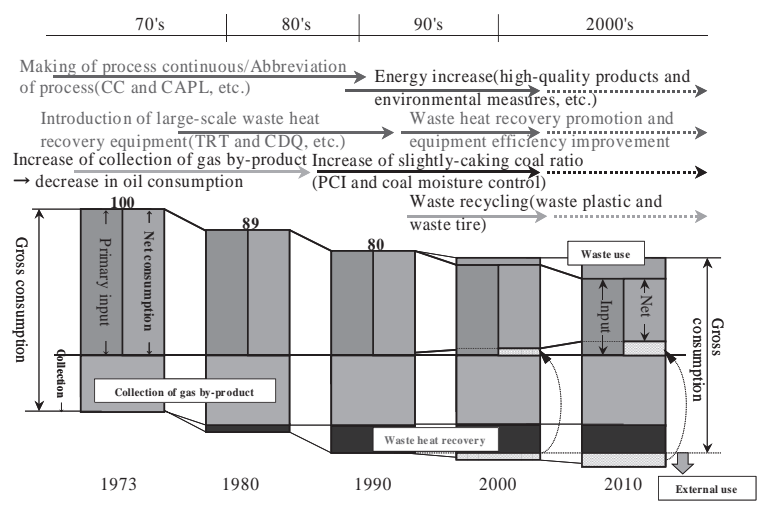

Fig.2 Transition of energy saving results since the first oil crisis in Japan.

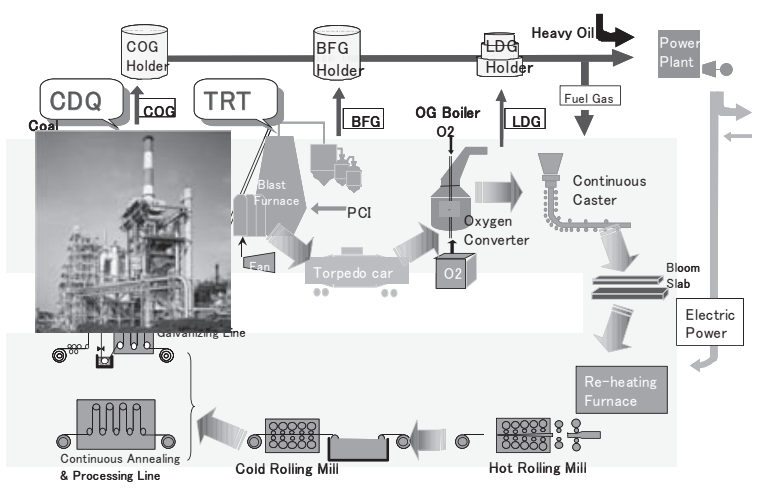

Fig.3 Energy saving technologies in steel works in Japan.

\section{2 具体的な省エネルギー技術}

製鉄所での省エネルギー技術の概要を Fig.3に示す。操 業改善は、ヒートパターンの改善、燃焼制御、燃焼用空気 予熱、計算機制御の導入等である。工程連続化や工程省 略は、連続鋳造 (CC：Continuous Casting)、直送圧延 (DR： Direct Rolling)、熱片装入 (HCR：Hot Charge Rolling)、連続 焼鈍 (Continuous Annealing) である。排エネルギー回収は、 コークス乾式消火設備 (CDQ : Coke Dry Quenching)、高炉 炉頂圧発電 (TRT：Top pressure Recovery Turbine)、転炉ガス 回収設備 (Converter Gas Recovery)、熱風炉排熱回収設備 (Hot Stove Exhaust Heat Recovery)、焼結排熱回収設備 (Sintering Machine Exhaust Heat Recovery)、石炭調湿装置 (CMC：Coal Moisture Control) である。本章では、1973 年以降の省エネ ルギーへの貢献度が大きい主要な排エネルギー回収の実用 化例を以下に紹介する。

\subsection{1 コークス乾式消火設備 (CDQ：Coke Dry Quenching)}

CDQ(Coke Dry Quenching、Fig.4)では、赤熱コークスは 従来の湿式消火法 (Coke wet quenching) のように水で消火 されるのではなく、窒素等の不活性ガスで消火される。高 温となった不活性ガスは排熱ボイラに導かれて約 $500^{\circ} \mathrm{C} の$ 高圧蒸気として回収され、発電に利用される。回収蒸気量

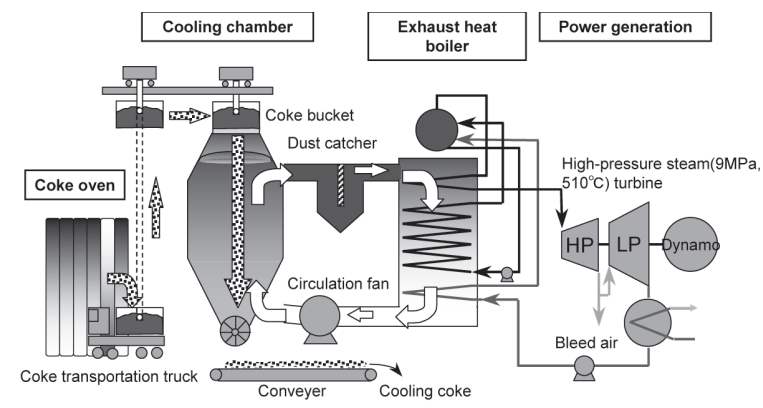

Fig.4 CDQ(coke dry quenching) -one of energy saving technologies.

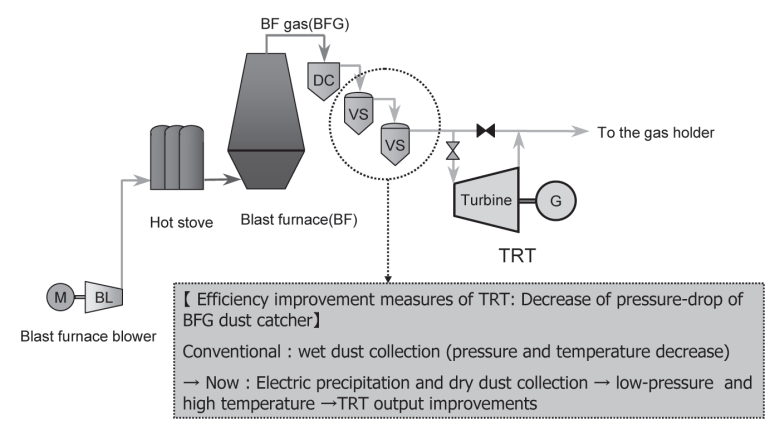

Fig.5 TRT(top-pressure recovery turbine) -one of energy saving technologies.

はコークス $\mathrm{t}$ 当たり $450 \sim 600 \mathrm{~kg}$ となり、カロリー換算で $20 \sim 30$ 万 $\mathrm{kcal}^{2)}$ である。本設備の普及率は $90 \%$ （2005 年） である ${ }^{4)}$

2.2.2 高炉炉頂圧発電 (TRT：Top pressure Recovery Turbine)

TRT(Top pressure Recovery Turbine、Fig.5) では、高炉炉 頂部から排出されるガス圧力によりタービンを回転させて 発電するもので、銑鉄 $\mathrm{t}$ 当たり $30 \sim 40 \mathrm{kWh}$ の省エネルギー になる。従来の湿式集塵から乾式集塵、電気集塵への集塵 方式の改善により、省エネルギー量はさらに増加する。本 設備の普及率は $100 \%$ （2001 年）であり ${ }^{5)}$ 、TRTによる年 間発電量は 30 億 $\mathrm{kWh}$ で一貫製鉄所の電力使用量の $8 \%$ を 占めている ${ }^{3)}$ 。

2.2.3 熱風炉排熱回収設備 (Hot Stove Exhaust Heat Recovery)

約 $250^{\circ} \mathrm{C}$ で排出される燃焼排ガスから回収した顕熱を燃 焼用空気あるいは燃料ガスの予熱に活用することで、省エ ネルギーを図る設備である (Fig.6)。本設備の普及率は $98 \%$ (2001 年) である ${ }^{5)}$ 。

2.2.4 転炉ガス回収設備 (Converter Gas Recovery)

炉口部の空気を遮断し排ガスを未燃焼のまま回収するも ので、省エネルギー量は粗鋼 $\mathrm{t}$ 当たり $20 \sim 24$ 万 kcal であ る (Fig.7)。本設備の普及率は $90 \%$ 以上である ${ }^{2)} 。$ 回収され る転炉ガスは転炉出口で $1450^{\circ} \mathrm{C}$ と高温であるため、この顕 熱を蒸気回収する顕熱回収設備も普及してきている。

2.3 高炉への微粉炭吹込み技術と還元材比低減 


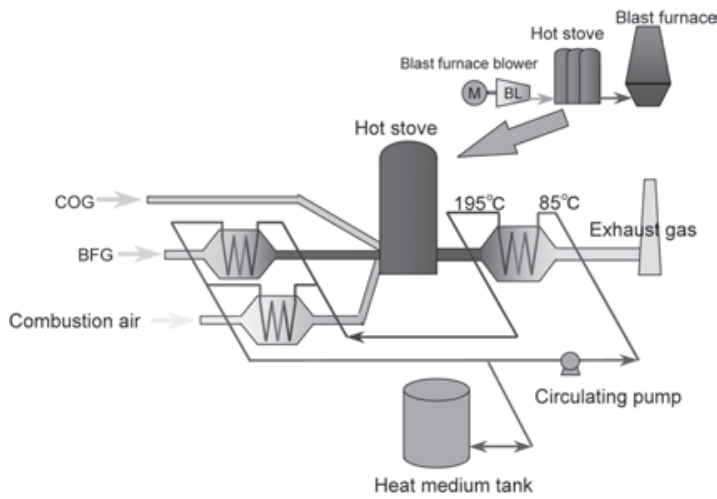

Fig.6 Waste gas recovery of hot stove one of energy saving technologies.

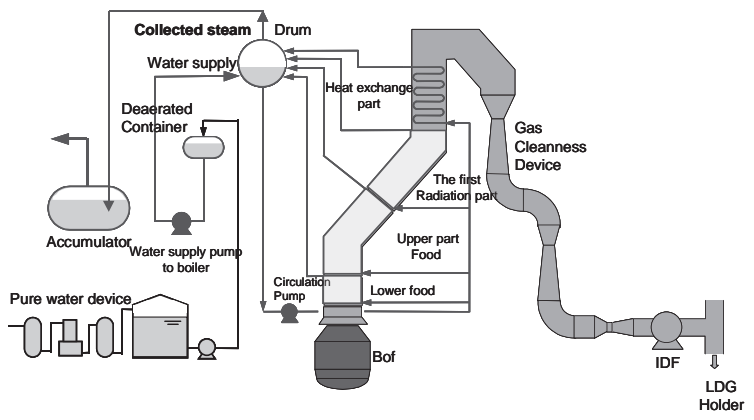

Fig.7 Waste gas recovery of converter-one of energy saving technologies.

日本での高炉への微粉炭吹込み技術は、それまで高炉に 吹き込まれていた重油の代替を目的として1981 年新日鐵 の大分 1 高炉に導入された。その後微粉炭吹込みを開始す る高炉の本数が増加し、1998 年には日本の全高灯への微 粉炭吹込及設備の装備が完了した。そして、全高炉の微粉 炭比 (PCR) の年間平均值は $130 \mathrm{~kg} / \mathrm{t}$ に到達し、コークス比 (CR) の低減に貢献した (Fig.8)。2000 年以降、 $\mathrm{CO}_{2}$ 削減の 観点から微粉炭比一定での還元材比 (RAR) の低減を指向し (Fig.8)、高出銑比・高微粉炭比操業条件下での装入物分布 制御のや装入物品質》の改善に取り組んでいる。並行して 日本の鉄鋼各社や大学では、多面的な観点からの更なる還 元材比低隇への取り組み ${ }^{8-10)}$ が検討されている。

\section{3. 日本鉄鋼連盟自主行動計画}

3.1 数值目標と取組状況

日本鉄鋼連盟は 1996 年 12 月に、鉄鋼業の環境保全に関 する自主行動計画 ${ }^{11,12)}$ を発表した(Fig.9)。自主行動計画 では、1）鉄鋼生産工程に扔ける省エネルギー（2010 年度 のエネルギー消費量を 90 年度に対して $10 \%$ 削減)、2）廃 プラスチック等の有効活用（集荷システムの確立を前提に 100 万 $\mathrm{t}$ 活用)、3) 製品·副産物による社会での省エネルギー、 4）国際技術協力による省エネルギー貢献、5）未利用エネ ルギーの近隣地域での活用を目標としている。鉄鋼業

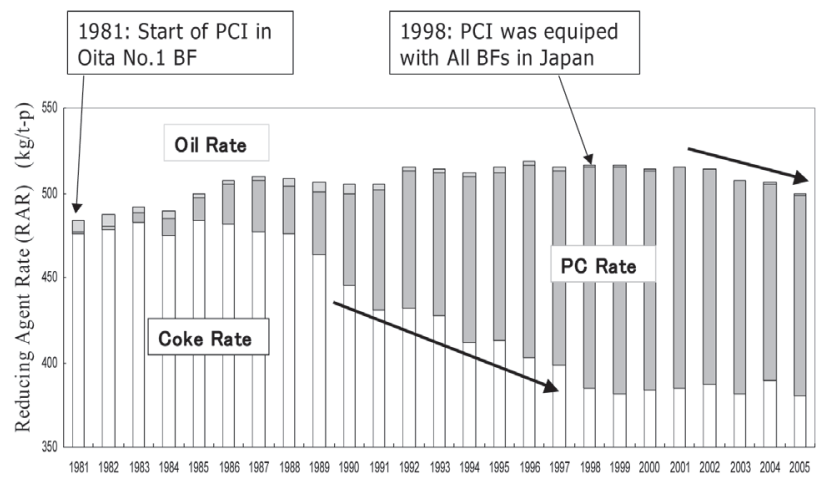

Fig.8 Transition of RAR, PCR, OilR \& CR.

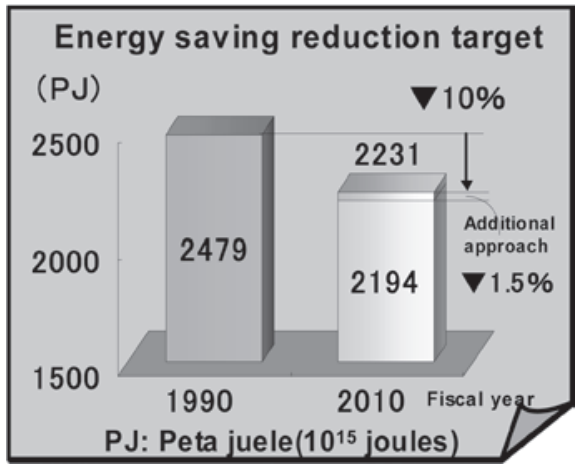

Fig.9 Voluntary action plan of Japan Iron and Steel Federation.

以外の業種に抢いても、それぞれの特徵を活かした自主行 動計画が策定されており、全体で日本経団連自主行動計画 を構成している。

京都議定書の発効によって、我が国の温室効果ガスの削 減目標（基準年－6\%）は国際公約となった。日本政府は 目標実現に向けて京都議定書目標達成計画を策定したが、 その中で自主行動計画は最も重要な柱となっている。

3.21990 年以降の省エネルギー実績

2002 年時点での省エネルギーは、1990 年基準で $6.6 \%$ 減 (省 $\mathrm{CO}_{2}$ でみると $6.9 \%$ 減)を達成している (Fig.10)。しかし、 2010 年の目標 (1990 年基準で $11.5 \%$ 減) を達成するために は、従来の省エネルギー技術の一層の普及推進、改善技術 の導入による未回収エネルギーの有効利用 (Fig.11) と新し い省エネルギー技術の適用が必要と考えられる。

\section{4. 新しい省エネルギー技術}

直近取り組まれている新しい省エネルギー技術を下記に 記載する。本論文では省略するが、2030 年の水素社会の実 現に向けて、水素製造 ${ }^{13)} 、 \mathrm{CO}_{2}$ 分離・貯蔵等の中期的な研 究開発の取り組みも開始されている。 


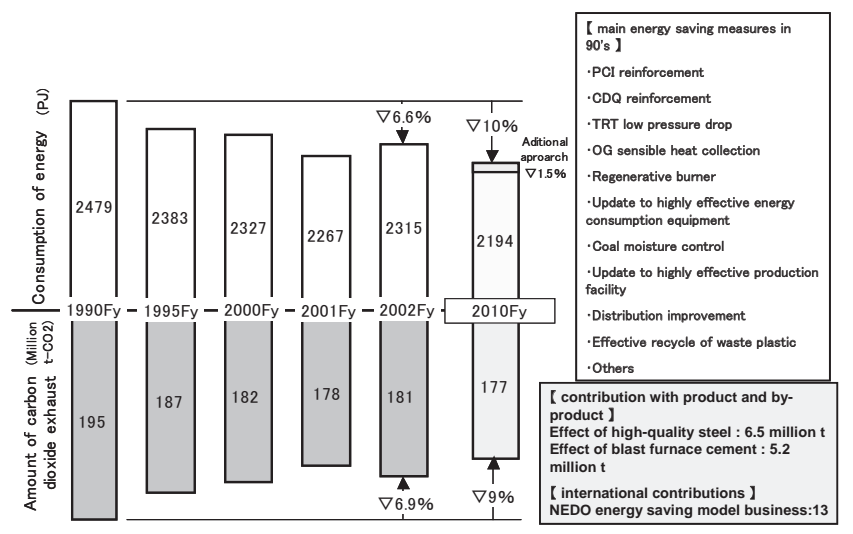

Fig.10 Transition of energy saving results since 1990 in Japan.

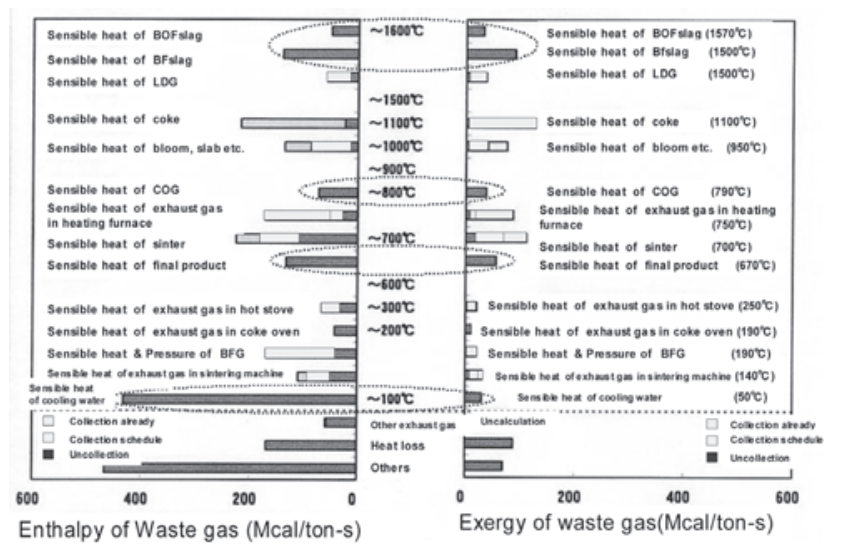

Fig.11 Waste gas and heat recovery in steel works.

\section{1 製鉄所内で発生するダスト・スラッジのリサイクル}

製鉄所発生ダスト・スラッジは焼結機、高炉や転炉で再 利用されているが、鉄分やC 分を含む高悪鉛ダスト・スラッ ジの大部分は埋め立てられている (Fig.12)。上記鉄分やC 分を有効に回収するために、製鉄所で発生する低水分・高 亜鉛のダストをペレット化し、還元・脱亜鉛して還元ペレッ トを製造する RHF(Rotary Hearth Furnace) 設備が 2000 年 5 月君津製鉄所に導入された $(F i g .13)^{14)}$ 。圧壊強度 $100 \mathrm{kgf} / \mathrm{cm}^{2}$ の還元ペレットは高炉に装入され高炉の還元材比低減に貢 献している (Fig.14)。生産率・脱业鉛率・金属化率の実績 值は当初の計画值を達成している。さらに 2002 年には高水 分のスラッジを処理できる RHF 設備が実機化されている。

\section{2 社会で発生する廃棄物のリサイクル}

国土の狭い日本では、廃棄物の中間処理は焼却を基本と している。そのため、焼却炉は多量のエネルギーを消費し $\mathrm{CO}_{2}$ の発生に繋がっている。鉄鋼プロセスにおいて廃棄物 を原料炭の代替として利用できれば、焼却炉に投入される エネルギーを削減できるため、社会全体としての資源節約、 $\mathrm{CO}_{2}$ 削減に貢献するものと期待されている。

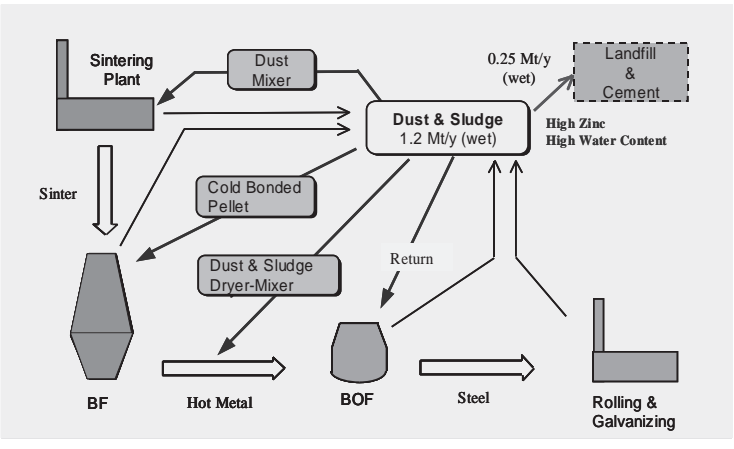

Fig.12 Material flow of dust \& sludge at Kimitsu works before 1999.

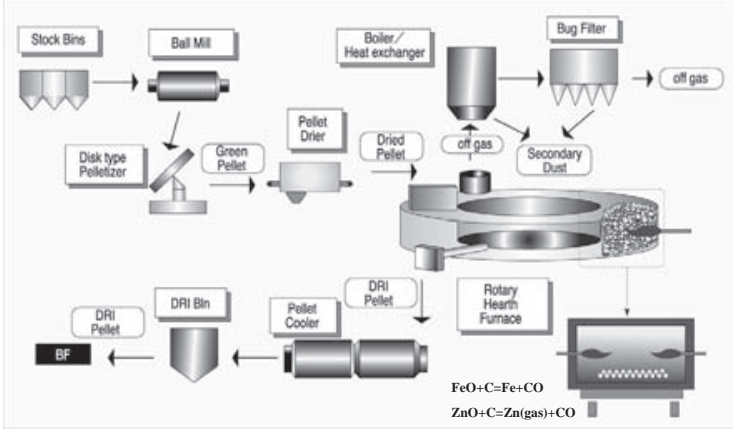

Fig.13 Process configuration of No.1 RHF plant.

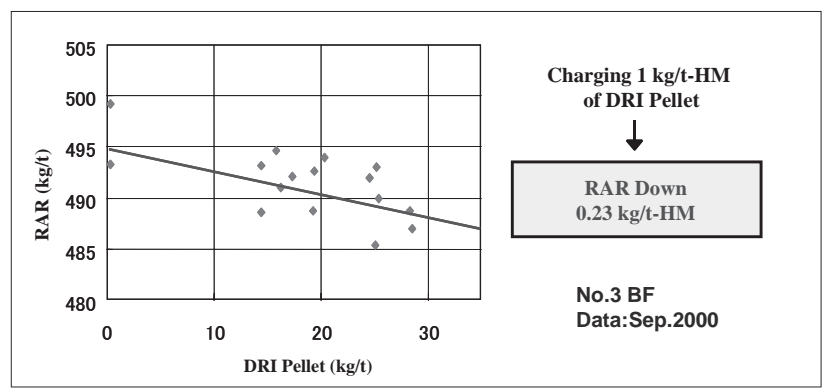

Fig.14 Effect of DRI pellet charging on RAR of the blast furnace.

\subsection{1 廃プラスチックのリサイクル}

一般 (municipal) 廃プラスチックの年間発生量は約 1000 万 $\mathrm{t}$ 年と推定されている (Fig.15)。一般廃プラスチックの リサイクルに関しては様々な方法が提唱されている ${ }^{15)}$ 。日 本鉄鋼業では、製銑工程の既設インフラを利用した一般廃 プラスチックの再利用を開始している。JFE スチールの 京浜製鉄所では、1996 年から適正な粒度に粉砕された廃プ ラスチックの高炉羽口からの吹込みが行われ (Fig.16)、廃 プラスチックは高炉還元材 $(12 \mathrm{~kg} / \mathrm{t})$ として利用されている 15)。一方新日鐵の名古屋製鉄所と君津製鉄所にて、2000 年 から廃プラスチックのコークス炉への装入が行われている 16)。装入された廃プラスチックは石炭とともに乾留され、 


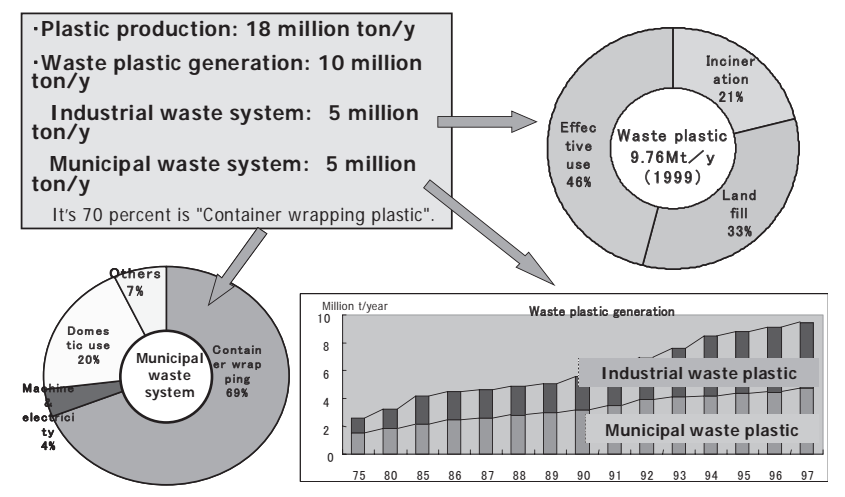

Fig.15 Material balance of waste plastic in Japan.

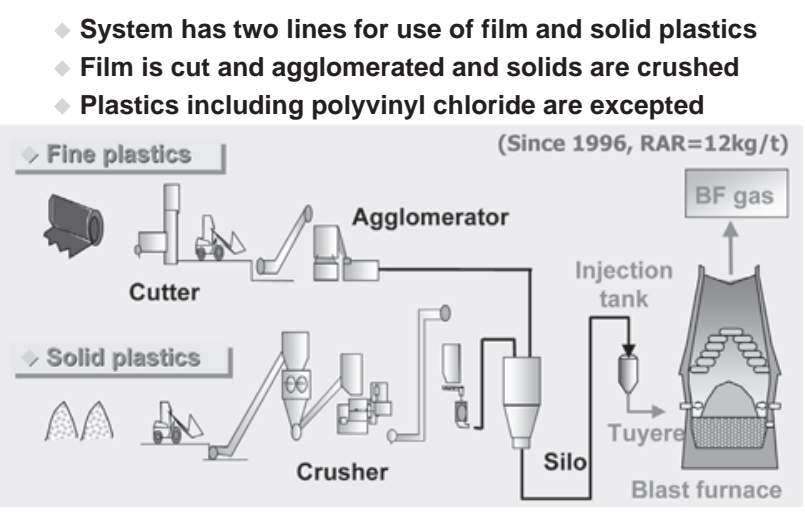

Fig.16 Waste plastic recycling into blast furnace.

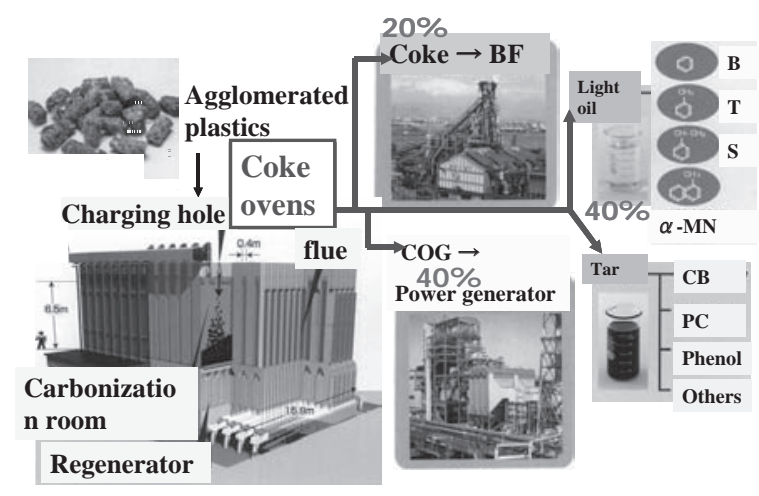

Fig.17 Waste plastic recycling into coke oven.

炭化水素油 (40\%) ・ コークス炉ガス $(40 \%)$ ・コークス $(20 \%)$ としてほほ回収されている(Fig.17)。原料炭に対して $1 \%$ の添加ではコークス品質への影響はないが、 $2 \%$ 以上では コークス強度が低下する。上記の課題を解決するための研 究開発が現在行われている。2002 年から八幡製鐵所と室蘭 製鐵所でも廃プラスチックのコークス炉での再利用が開始

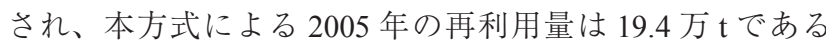
17,18)。

4.2.2 廃タイヤのリサイクル

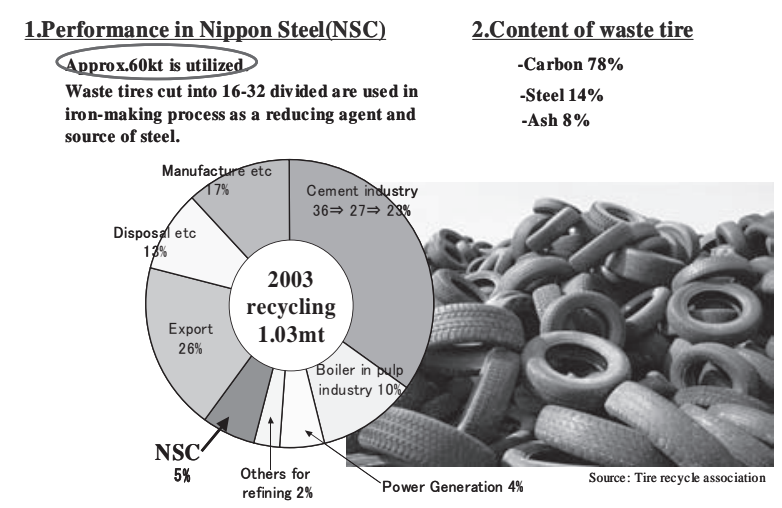

Fig.18 Material balance of waste tire in Japan.

廃タイヤの年間発生量は約 100 万 $\mathrm{t} /$ 年と推定されてい る。セメント業界、製紙業界、発電業界等が廃夕イヤのリ サイクルを行っている。鉄鋼業でも廃夕イヤが冷鉄源溶解 炉 (SMP : Scrap melting process) や外熱式ロータリーキルン (External heating type rotary kiln) に装入され、廃夕イヤ中の $78 \%$ の炭素、14\%の鋼がガスや溶鋼として回収されている ${ }^{19)}$ (Fig.18)。2005 年の廃夕イヤの再利用量は約 9 万 t である。

鉄鋼プロセスを活用した廃プラスチックや廃タイヤのリ サイクルについては、システム拡張法による環境評価の試 みも行われている ${ }^{20)}$ (Fig.19)。

4.3 次世代製鉄技術の等の導入促進

いままでに、溶融還元製鉄法 $(\mathrm{DIOS}) 、$ 次世代コークス製 造技術 (SCOPE21)、スクラップ多量使用技術（新製鋼プロ セス）ほかのいろいろな次世代製鉄技術が国家プロジェク トとして推進されてきた。その中のひとつである SCOPE21 の実用化に向けて、商用一号機の建設工事が新日鐵の大分 製鉄所にて開始されている。

コークス炉の寿命延長対策（目標 $=50$ 年 -55 年）とし て精力的に取り組まれている炉体の診断技術と補修技術を 適用したとしても、近い将来にコークスの大量の不足が予 想されている (Fig.20)。上記背景に加えて、資源制約、低 生産性、エネルギー多消費構造および環境問題等の問題を 解決するために、日本の鉄鋼各社は、新たなコークス製造 プロセス開発の国家プロジェクト (SCOPE21) を共同で 1994 年から推進してきた ${ }^{21)}$ (Fig.21)。

SCOPE21 は3つの工程に分割されている (Fig.22)。す なわち、石炭の急速加熱、石炭の低温乾留と低温乾留され たコークスの加熱・改質である。以上の 3 つの工程からな る新しいコークス製造技術を開発することにより、従来の コークス製造プロセスをコンパクト化し、非常に効率の良 いコークス製造プロセスを実現することを目的としてい る。以下に SCOPE21 の特徵を示す。

4.3.1 石炭資源の有効利用

コークスの冷間品質は、石炭の乾燥と微粉の塊成化によ 


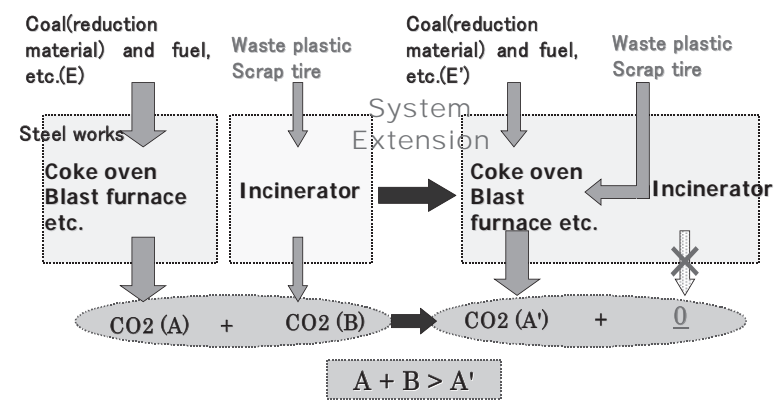

Fig.19 One example of environmental evaluation of waste recycling.

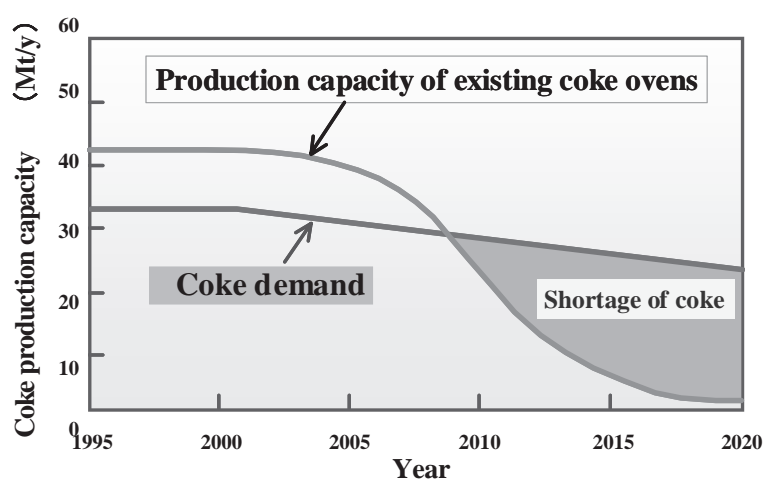

Fig.20 Estimated demand and supply of coke in Japan.

Fiscal year

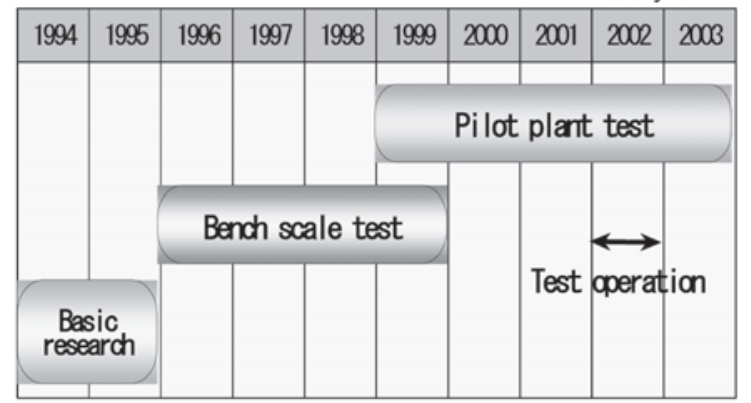

Fig.21 SCOPE21 development schedule.

る密度向上効果に加えて急速加熱効果により改善される (Fig.23)。上記の冷間強度改善効果により、冷間強度一定の 条件下で非微粘結炭の比率を $20 \%$ から $50 \%$ に向上させる ことが可能となる。

\subsection{2 高生産性}

高生産性は下記の新しい技術により達成される。すなわ ち、乾燥温度の $200^{\circ} \mathrm{C}$ から熱分解が開始する温度域である $350-400^{\circ} \mathrm{C}$ の石炭の急速加熱、コークス炉炭化室での 高熱伝導度レンガの使用と低温窯出しによるコークス化時 間の実質的な短縮であり、生産性は 2.4 倍になる (Fig.24)。 低温で窯出ししたコークスの冷間強度を補填するために、

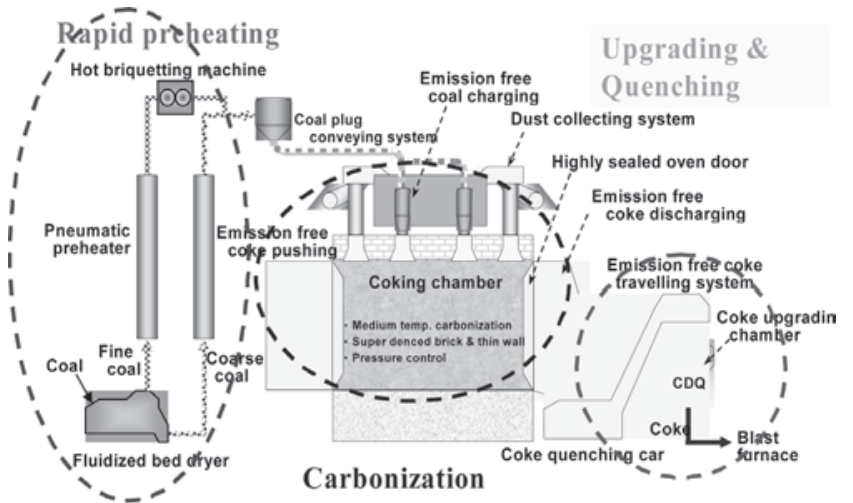

Fig.22 Schematic diagram of SCOPE21 process flow.

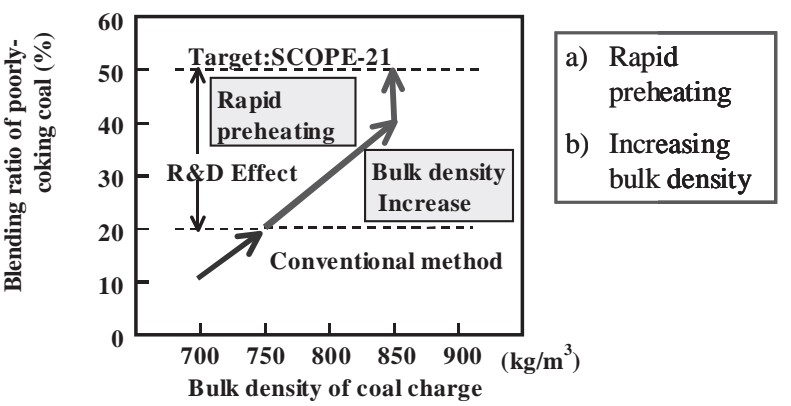

\section{Non or slightly caking coal from $\mathbf{2 0} \%$ to $\mathbf{5 0} \%$}

Fig.23 Technologies for improving coke quality.

コークスは CDQ 内にて再加熱される。

4.3.3 省エネルギー

省エネルギーは急速加熱による乾留開始温度の上昇と宰 出し温度の低下による乾留エネルギーの低減により達成さ れる (Fig.25)。さらに、乾留時に発生するガスと燃焼排ガ スの顕熱の回収により $21 \%$ の省エネルギーが達成される。

\subsection{4 環境改善}

石炭やコークスのチューブコンベヤの活用、コークス炉 からのガス漏れ防止により、コークス炉周辺の環境は改善 される。さらに、コークス炬での燃焼システム改善により NOx が低減される (Fig.26)。

実用化プラントのイメージを Fig.27に示す。新コークス 炉の製造能力は約 4000t/d であり、 $4000 \mathrm{~m}^{3}$ 級の高炉のコー クス使用量にほぼ対応している。SCOPE21 プロセスは従 来のプロセスに比べて高生産性のため窯の数は大幅に少な く、コンパクトなプロセスになっている。

4.4 その他の取り組み ${ }^{3,4), 11}$

4.4.1 製品・副産物による社会での省エネルギー

鉄鋼業では、製造工程の省エネルギーだけではなく、よ 


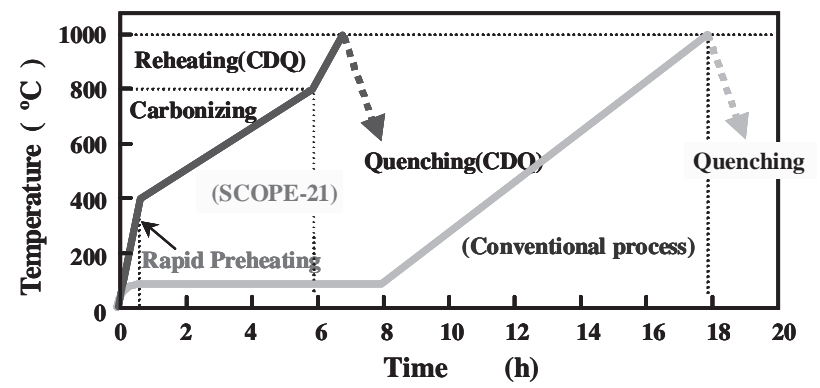

Productivity of SCOPE21: 24 times as high as conventional process

Fig.24 Coking time of SCOPE21 process.

\section{The SC O PE 21 process can reduce net heat consumption by $21 \%$.}

* Preheating the coal charge $\left(330-380^{\circ} \mathrm{C}\right)^{*}$ L owering the coke discharging temperature $\left(900{ }^{\circ} \mathrm{C}\right)$

Fig.25 Energy saving of SCOPE21 process

\section{NO $x$ concentration in combustion gas < 100 ppm}
* Uniform heating* L ow NOX emmision

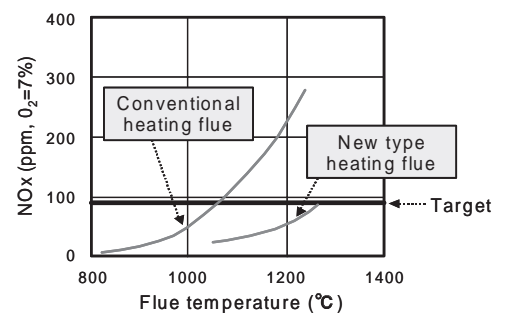

Fig.26 Low NOxCombustion of coke Oven.

り高品質な低環境負荷鉄鋼製品（高張力鋼板 ${ }^{22}$ ：自動車の 燃費向上効果、表面処理鋼板：自動車の平均寿命延長効果、 電磁鋼板 ${ }^{23)}$ : トランス電力ロス減少効果、ボイラー用鋼管： 伝熱効率向上効果）を開発し提供してきた。こうした鉄鋼 製品では、従来の製品に比較して、生産工程でのエネルギー 消費量は増加するが、ライフサイクルからみた製品のエネ ルギー消費量は低下し、社会全体としては省エネルギーに 貢献している (Fig.28)。

年間約 2000 万 $\mathrm{t}$ 強の発生量がある高炉スラグはそのほ とんどが有効利用され (Fig.29)、65\% はセメント用原料と して使用されている。高炬スラグをセメント製造に利用す ると焼成工程が省略され、セメント製造における省エネル

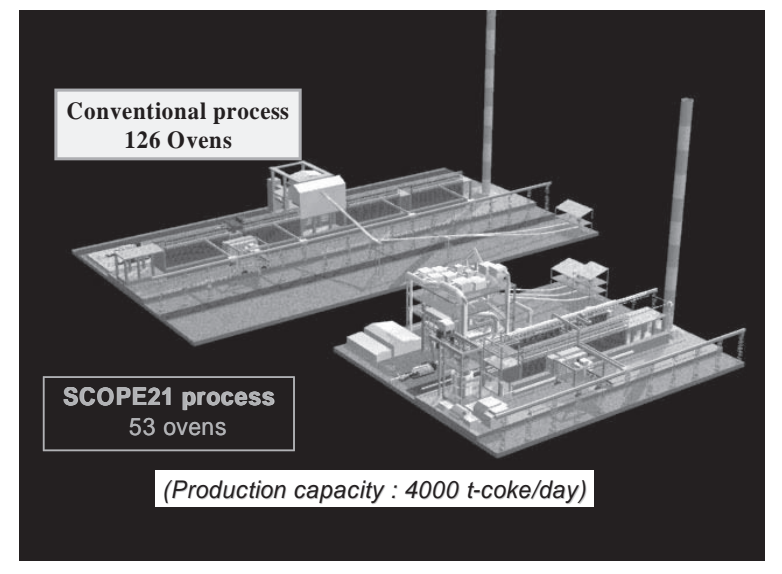

Fig.27 Commercial plant of SCOPE21

Amount of $\mathrm{CO}_{2}$ reduction of steel material use stage in 2000

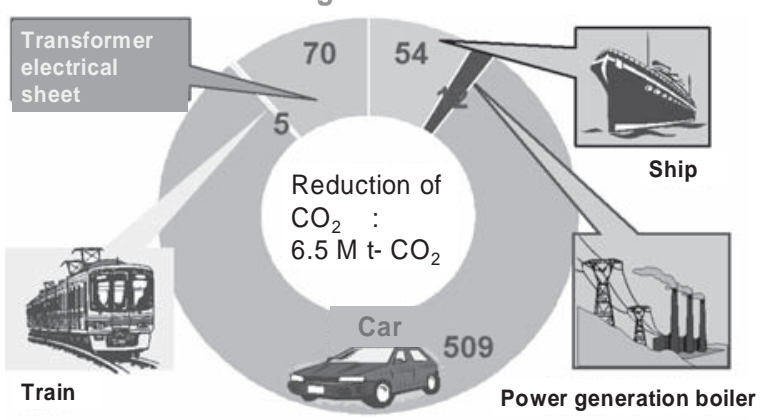

Fig.28 Energy saving due to high quality steel products.

ギー（セメント $1 \mathrm{t}$ 当たり $35 \%$ の省エネルギー）に貢献し ている。高炉スラグの利用による省エネルギー量は年間 57 万 $\mathrm{kl}$ (重油換算) であり、鉄鋼業のエネルギー消費量の約 $1 \%$ に相当すると試算されている。

4.4.2 国際協力による省エネルギー

日本鉄鋼業では、優れた省エネルギー技術や環境対策技 術が開発・実用化されている。これらの技術を、中国やイ ンドなど、鉄鋼生産が急激に拡大している発展途上国に移 転し、世界の鉄鋼業全体で $\mathrm{CO}_{2}$ の削減を図っていこうとす る取り組みが行なわれている。中でもアジア・太平洋パー トナーシップ (APP) は、日・中・印・韓・米・豪の 6 ケ 国が協力して、鉄鋼を含む 8 つ技術領域における環境問 題を技術的に解決していこうとするもので、京都議定書を 補完する取り組みとして大きな期待が寄せられている。鉄 鋼分野では日本が議長国となり、先端技術ハンドブックの 作成、設備装備率・実力調査の実施、技術移転による削減 ポテンシャル調査、実行プログラムの策定が、6ヶ国協力 の下鋭意行なわれている。

4.4.3 地域連携、産業間連携による省エネルギー

一貫製鉄所では排熱利用が進められ、発電、予熱等に有 


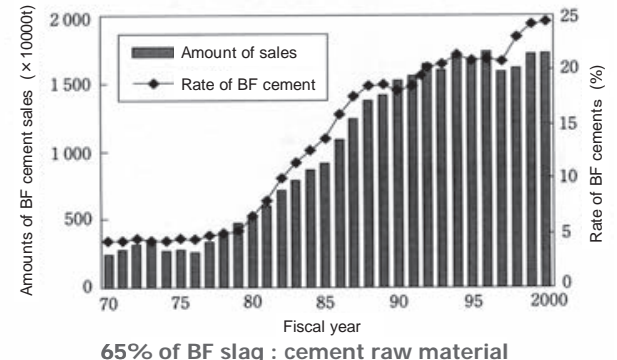

$65 \%$ of BF slag : cement raw material

Fig.29 Transition of sales amounts of BF slag cements in Japan.

効に活用されている。今後の課題は、工業的な利用は困難 であるが近隣の民生用としては十分再利用可能な顕熱等の 中低温排熱の有効利用である。直近では、製鉄所を核とし た地域連携、産業間連携の例として、製鉄所を基盤とした 循環型社会構想が提案されている (Fig.30)。

\section{5. 結 言}

(1) 1973 年の第一次石油危機を契機に省エネルギーが推進 され、各設備におけるきめ細かな操業改善、工程連続 化や工程省略等の生産設備の高効率化、排熱回収設備 の導入や副生ガス回収強化の排エネルギー回収等によ り $20 \%$ の省エネルギーを達成した。

(2) 1996 年 12 月に日本鉄鋼連盟では、地球温暖化防止と循 環型社会の構築を柱とした自主行動計画を策定し、粗 鋼生産量 1 億 $\mathrm{t}$ を前提に、2010 年の総エネルギー消費 量を 1990 年に比較して $11.5 \%$ 削減する目標を掲げて推 進中である。

\section{引用 文 献}

1) 石弘之: $\mathrm{CO}_{2}$ 削減に向けての鉄鋼技術の進展, 日本鉄鋼協会編, 東京 (2006), 3 .

2) 鉄鋼業における省エネルギー対策, 鉄鋼界, 日本鉄鋼連盟編、 東京 (1990), 19.

3) 西澤庄蔵：鉄鋼業における省エネルギー技術, 鉄鋼界, 日本 鉄鋼連盟編，東京 (2001)，4.

4) 鉄鋼業の地球温暖化対策への取り組み 自主行動計画進渉状 況報告、日本鉄鋼連盟、(2007).

5) I.Ogata and M.Sanui : The latest trend and future aspect in Japanese ironmaking technology, Proceedings of the $3 \mathrm{rd}$ International Conference on Science and Technology of Ironmaking, VDEh, Dusseldof, (2003), 57.

6) S.Watakabe, K.Takeda, H.Nishimura, S.Goto, N.Nishimura, T.Uchida and M.Kiguchi : Tetsu-to Hagane,92(2006),209.

7) M.Naito, Y.Hosotani, K.Yamaguchi, M.Higuchi, Y.Inoue and T.Haga : CAMP-ISIJ,9(1996), 627.

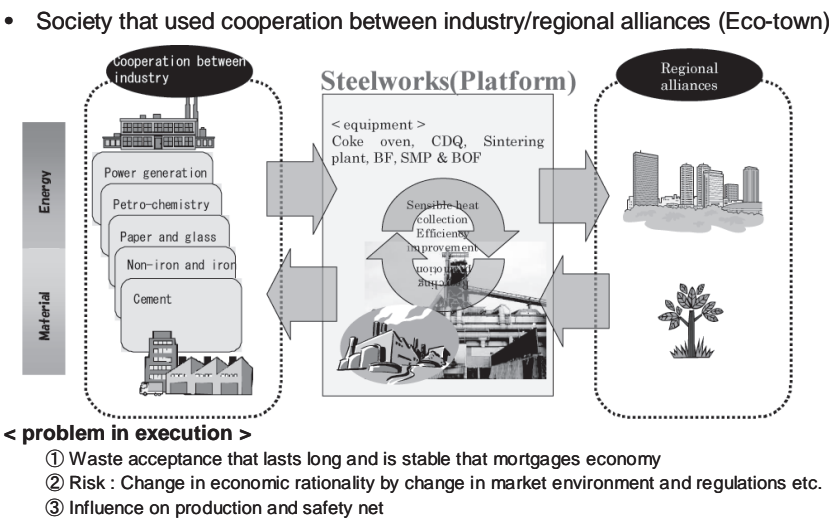

Fig.30 Construction of recycling society that makes iron and steel industry platform.

8) K.Ishii : ISIJ International, 44(2004), 1969.

9) K.Kunitomo, Y.Takamoto, M.Naito and J. Yagi : J.Jpn. Inst. Energy, 84(2005), 126.

10) M. Nakano, M. Naito, K. Higuchi and K. Morimoto: ISIJ International, 44(2004), 2079.

11) S.Nishizawa : Approach to Environmental Protection in Japan' $S$ Steel Industry, IISI-36, Conference Papers6, (2002).

12) 井上清彦：地球温暖化問題の動向と鉄鋼業の対応，ふえらむ, 4(1999)6, 357.

13) 永浜洋：製鉄プロセスから生まれた新たな環境技術と今後の 可能性, 日本鉄鋼協会編, (2004), 23.

14) H.Oda, T.Ibaraki and Y.Abe : Nippon Steel Technical Report, 384(2006), 134.

15) M. Asanuma: SHIGEN-TO-SOZAI, 116(2000), 737.

16) K. Kato, I. Komaki and H. Uematsu: Met. Technol. (Jpn.), 71(2001), 331.

17) K. Kato, S. Nomura, H. Uematsu and H. Kondo: J. Jpn. Inst. Energy, 83(2004), 166.

18) K.Kato, S.Nomura, K.Fukuda and H.Uematsu : Proceedings of the 5 th European Coke and Ironmaking Congress, JERNCONTRET, Stockholm, 2(2005), we6:1-1.

19）高松信彦：資源生産性向上に向けての素材技術の役割，日本 鉄鋼協会編, 東京 (2004), 57.

20) K.Kato, K.Fukuda and N.Takamatsu : J.Jpn. Inst. Energy, 84(2005), 248.

21) I.Sugiyama, K.Kato, H.Fujikawa, K.Nishioka and H.Oshima : Proc. of $5^{\text {th }}$ ECIC, JERNKONTRET, Stockholm, (2005), We6:4.

22) 牛神義行：電磁鋼板はエコマテリアル，ふえらむ，4(1999)6, 363.

23）伊藤颚、岸田宏司、栗山幸久：自動車の軽量化に資する鉄鋼 材料, ふえらむ, 4(1999)6, 363. 